\title{
THE BLOOD IN CASES OF UNEXPLAINED GASTRIC ANACIDITY ${ }^{1}$
}

\author{
By W. SCOTT POLLAND 2 \\ (From the Department of Medicine, Stanford University Medical School, San Francisco)
}

(Received for publication January 23, 1933)

The question of the relationship of gastric anacidity to anemia has recently been the subject of renewed interest and study. Some writers believe that people with unexplained achlorhydria are potential cases of pernicious anemia, subacute combined sclerosis or hypochromic anemia ${ }^{3}$ (microcytic, idiopathic, achylic, simple). Others, however, feel that the view that anacidity bears a causal relationship to these disorders requires further support and that in most cases defective gastric secretion is a harmless variation from the normal.

While it must be admitted that many patients with anemia have a gastric anacidity no comparative study, as far as we know, has been made of the blood in comparable groups of people on the one hand with defective and on the other with normal gastric juice; inasmuch as a control of this sort seems fundamental in interpreting the problem we have carried out such observations and they are herewith reported.

\section{LITERATURE}

Einhorn (1) (1892) demonstrated that anacidity can be present for several years without the development of pernicious anemia. Later (1903) he (2) found some degree of anemia in twelve out of fifteen cases and in four the hemoglobin was below 60 per cent. Three of these patients probably had pernicious anemia.

At the International Congress of Medicine in London (1913) Faber (3) proposed that the anemia frequently associated with achylia gastrica, was a secondary phenomenon produced by an absence of gastric secretion. Among two hundred and one cases of achylia gastrica, Faber found fiftynine with a hemoglobin below 80 per cent. Twenty-two were examples of Addison's anemia, and thirty-seven, of simple anemia. Twenty-two of the cases of simple anemia were severe, the hemoglobin being below 65 per cent. Weinberg (4) (1920) states that the blood picture is often

${ }^{1}$ Supported, in part, by a grant from the Rockefeller Fluid Research Fund of the School of Medicine, Stanford University.

2 Fellow in Medicine, National Research Council, 1932-1933.

3 For the purpose of convenience, this condition will be referred to in this paper as hypochromic anemia. 
abnormal in anacidity, but Alsberg (5) (1921) noted anemia in only one of his seventy cases. Hurst has maintained for many years that the absence of hydrochloric acid from the gastric secretion is the essential predisposing cause of Addison's anemia and subacute combined sclerosis. For his conceptions, the reader is referred to his papers which have been collected into a single volume (6).

Hunter (7) (1923) analyzed the findings in sixty patients with anacidity most of whom had chronic diarrhea. Seven had a moderate or severe secondary anemia. Faber and Gram (8) (1924) restudied the problem in a new series of ninety cases excluding those with carcinoma, pernicious anemia or tuberculosis. Anemia was defined as a hemoglobin value less than 96 per cent in men and 88 per cent in women. The percentage of anemia was 41. Schneider and Carey (9) (1928) found in fifty-one cases of achlorhydria, seven with a high color index and seven with a secondary anemia. Borgbjaerg and Lottrup (10) (1929) state that 41 per cent of one hundred and thirty-four cases had a secondary anemia, usually of a mild degree, and that several had a color index over one. Lerman, Pierce and Brogan (11) (1932) observed in normal individuals that the red cell count and hemoglobin tended to vary directly with the level of gastric acidity.

Many cases have recently been reported, usually under the heading of hypochromic anemia. This disorder is described as an anemia with small erythrocytes and a low color index, occuring in middle aged women who have an anacidity.

A number of writers (Witts (12), Waugh (13), McCann and Dye (14), Dameshek (15), Mills (16), Davies (17), and VanderHoof and Davis (18)) believe that this syndrome is a specific disease and that the anacidity is an important etiological factor. However, Bloomfield (19) has critically reviewed the subject and pointed out that various degrees of anemia may be associated with anacidity and that all types of gastric secretion may be associated with anemia.

The fact that anacidity may precede pernicious anemia by an interval of from 3 months to 25 or more years, has been reported by at least eighteen authors. Ivy, Morgan and Farrell (20) have been able to collect a total of thirty-six reported cases. In a review of the hereditary aspects of achlorhydria in pernicious anemia, Conner (21) cites thirty-seven authors. He reports that among one hundred and fifty-four relatives of one hundred and nine patients having pernicious anemia, the percentage of anacidity was 25.9 , whereas among those of a control group, the percentage was 15.2.

Castle (22), (23), (24), (25) has demonstrated that normal human gastric juice can produce by interacting with beef muscle, a substance as effective as liver in promoting blood and clinical improvement in pernicious anemia. He believes that pernicious anemia is a deficiency disease 
brought about by defective digestion of protein, as a result of achylia gastrica. In support of this hypothesis, he reports a patient without anemia and three with hypochromic anemia, all of whom had an anacidity to histamine, but who nevertheless had the necessary hematopoietic stimulating substance present in their gastric juice. Barnett (26) using the same method of biologic assay was unable to confirm his results on two cases without anemia known to have had an anacidity for several years.

\section{MATERIAL AND METHODS}

The material consisted of twenty-six males and twenty-two females with unexplained anacidity as demonstrated by the previously described histamine technique (27). The anacidity was usually an accidental finding and most of the patients did not have a primary digestive complaint. Patients with carcinoma, pernicious anemia, hyperthyroidism, syphilis, fever, bleeding, or chronic wasting diseases, such as tuberculosis, were excluded. The known duration of the anacidity to histamine varied from 1 month to 4 years and 8 months. The average for the males was 27 months, and for the females, 19.4 months. In practically all of the cases, the family history was negative or no data was obtainable. In one case it was reported that a brother had died of pernicious anemia.

The following blood examinations were made: red and white cell counts, including a differential, hemoglobin (Sahli) and color index. In order to obtain more detailed data on the condition of the blood fifteen males and ten females were examined by workers specially trained in hematological methods. Red and white cell counts were made with standardized counting chambers and pipettes. In the differential counts of the leukocytes 200 cells were enumerated. Hemoglobin was determined by the oxygen capacity method of Van Slyke and Neill (28) and color indices were calculated on the basis of a correspondence of 5,000,000 corpuscles and 91 per cent hemoglobin equal to 15.6 grams of hemoglobin per $100 \mathrm{cc}$. of blood. Platelets and reticulocytes were counted by a method devised by Dr. Harry A. Wyckoff of the Stanford Medical School. The average diameter of the red corpuscles was measured by the PriceJones technique (29). The frequency distribution of the corpuscular diameters was determined with an ocular micrometer, measuring 200 corpuscles in freshly dried smears, fixed and stained with Wright's stain. Icterus indices and Van den Bergh tests were done in the usual manner.

For a control group, a similar study was made of fifteen males and eleven females of about the same age and physical status, who had, however, free acid in their gastric secretion. These subjects were chosen seriatim from a miscellaneous group of hospital patients, and the criteria for selection were the same as for the anacidity group. 


\section{RESULTS}

In Tables 1 and 2 the age, diagnosis and test meal findings ${ }^{4}$ are recorded for the control group. Patients with a wide variety of disorders and with every type of gastric secretion were used.

TABLE 1

Age, diagnosis and gastric secretory findings in male controls

\begin{tabular}{|c|c|c|c|c|c|}
\hline Case & Age & Clinical diagnosis & Volume & $\begin{array}{c}\text { Free } \\
\text { acidity }\end{array}$ & $\begin{array}{l}\text { Total } \\
\text { acidity }\end{array}$ \\
\hline & years & & $c c$. & m. $E q . / L$ & m. EQ./L. \\
\hline 1 & 31 & Indigestion, psychoneurosis & 60 & 92 & 102 \\
\hline 2 & 58 & Abdominal pain (unexplained) & 23 & 66 & 76 \\
\hline 3 & 42 & Pneumonoconiosis & 21 & 40 & 56 \\
\hline 4 & 42 & Abdominal pain (unexplained) & 23 & 78 & 96 \\
\hline 5 & 48 & Duodenal ulcer & 42 & 138 & 142 \\
\hline 6 & 57 & Gastric ulcer & 50 & 94 & 102 \\
\hline 7 & 46 & Psychoneurosis & 50 & 65 & 66 \\
\hline 8 & 32 & Psychoneurosis & 20 & 66 & 78 \\
\hline 9 & 46 & Irritable colon & 29 & 100 & 113 \\
\hline 10 & 28 & Psychoneurosis & 27 & 124 & 130 \\
\hline 11 & 40 & Indigestion & 17 & 112 & 120 \\
\hline 12 & 56 & Duodenal ulcer & 35 & 84 & 99 \\
\hline 13 & 55 & Gastric ulcer & 36 & 98 & 106 \\
\hline 14 & 68 & Chronic hepatitis ? & 2 & 25 & 35 \\
\hline 15 & 46 & Indigestion & $3 \overline{5}$ & 50 & 58 \\
\hline Average & 46.3 & & 31.6 & 82 & 92 \\
\hline
\end{tabular}

TABLE 2

Age, diagnosis and gastric secretory findings in female controls

\begin{tabular}{|c|c|c|c|c|c|}
\hline Case & Age & Clinical diagnosis & Volume & $\begin{array}{c}\text { Free } \\
\text { acidity }\end{array}$ & $\begin{array}{c}\text { Total } \\
\text { acidity }\end{array}$ \\
\hline $\begin{array}{r}1 \\
2 \\
3 \\
4 \\
5 \\
6 \\
7 \\
8 \\
9 \\
10 \\
11 \\
\text { Average }\end{array}$ & $\begin{array}{l}\text { years } \\
58 \\
63 \\
36 \\
71 \\
41 \\
48 \\
61 \\
76 \\
56 \\
57 \\
63 \\
\\
57.2\end{array}$ & $\begin{array}{l}\text { Arteriosclerosis and hypertension } \\
\text { Arteriosclerosis and hypertension } \\
\text { Duodenal ulcer } \\
\text { Psychoneurosis } \\
\text { Psychoneurosis } \\
\text { Hypertension } \\
\text { Auricular fibrillation } \\
\text { Cholelithiasis, diabetes mellitus } \\
\text { Chronic cholecystitis } \\
\text { Diabetes mellitus } \\
\text { Arteriosclerosis, diabetes mellitus }\end{array}$ & $\begin{array}{r}c c . \\
42 \\
2 \\
55 \\
35 \\
18 \\
2 \\
12 \\
16 \\
52 \\
32 \\
40 \\
27.8\end{array}$ & $\begin{array}{c}\text { m. Eq./L. } \\
105 \\
25 \\
52 \\
91 \\
91 \\
6 \\
60 \\
86 \\
74 \\
23 \\
104 \\
65.2\end{array}$ & $\begin{array}{c}\text { m. Eq./L. } \\
113 \\
35 \\
62 \\
96 \\
101 \\
20 \\
70 \\
100 \\
87 \\
43 \\
108 \\
76.8\end{array}$ \\
\hline
\end{tabular}

4 The highest 10 minute secretory volumes and highest free and total acidity after histamine are alone recorded. 
In Tables 3, 4, 5 and 6, a detailed report of the blood of the subjects who were especially studied is presented and in Table 7 the findings are summarized. A number of points revealed by those tables will be discussed.

Hemoglobin. The hemoglobin in the male anacidity patients ranged between 65.9 and 102 with an average of 87.6 per cent; in the controls between 80.2 and 100.9 with an average of 93.3 per cent. The average grams per cent for the anacidity group was 14.9 , and for the control group, 16.07 .

Hemoglobin in the female anacidity patients ranged between 54 and 95 with an average of 83.9 per cent; in the controls the values lay between 52.2 and 97.9 , with an average of 85.8 per cent. The average grams per cent for the anacidities was 14.42, and for the controls 14.68. The following cases had a marked lowering of hemoglobin: male anacidity Case 8, female anacidity Case 11, and female control Case 11 . Otherwise, the variations were about the same in both series.

Red cell counts. There was no striking difference in the red cell counts of the two groups. Male anacidity Cases 1 and 8 , female anacidity Case 9, and female control Case 11 had counts definitely below normal.

Color index. The majority of the color indices were about .9 or higher. Cases 2, 8 and 11 of the female anacidities, and Case 11 of the female controls, had indices below .8. More controls than anacidities had indices above 1.00 .

White cell count. All of the counts were within the range usually accepted for normal people. No anacidity case had a definite leukopenia nor was the differential count unusual in any of the cases.

Platelets. These varied considerably in both series, but were considered to be within the range of normal.

Reticulocytes. Cases 4,5 and 11 of the female anacidity group, and Case 6 of the male control group, showed a slight reticulocytosis.

Icterus index and van den Bergh. A number of individuals among both the "anacidities" and the controls had either an icterus index or Van den Bergh slightly above normal.

Price-Jones curve. There was no significant difference as regards the variation in size of red cells between the anacidities or controls.

Smear. Reports such as normal smear, slight anisocytosis, moderate polychromasia, etcetera, were not uncommon in either series. The impression of the worker studying the smear did not always correspond to the type of Price-Jones curve recorded, but usually there was a close agreement between the two. Case 11 of the female anacidities and Case 11 of the female controls had definitely abnormal smears. 


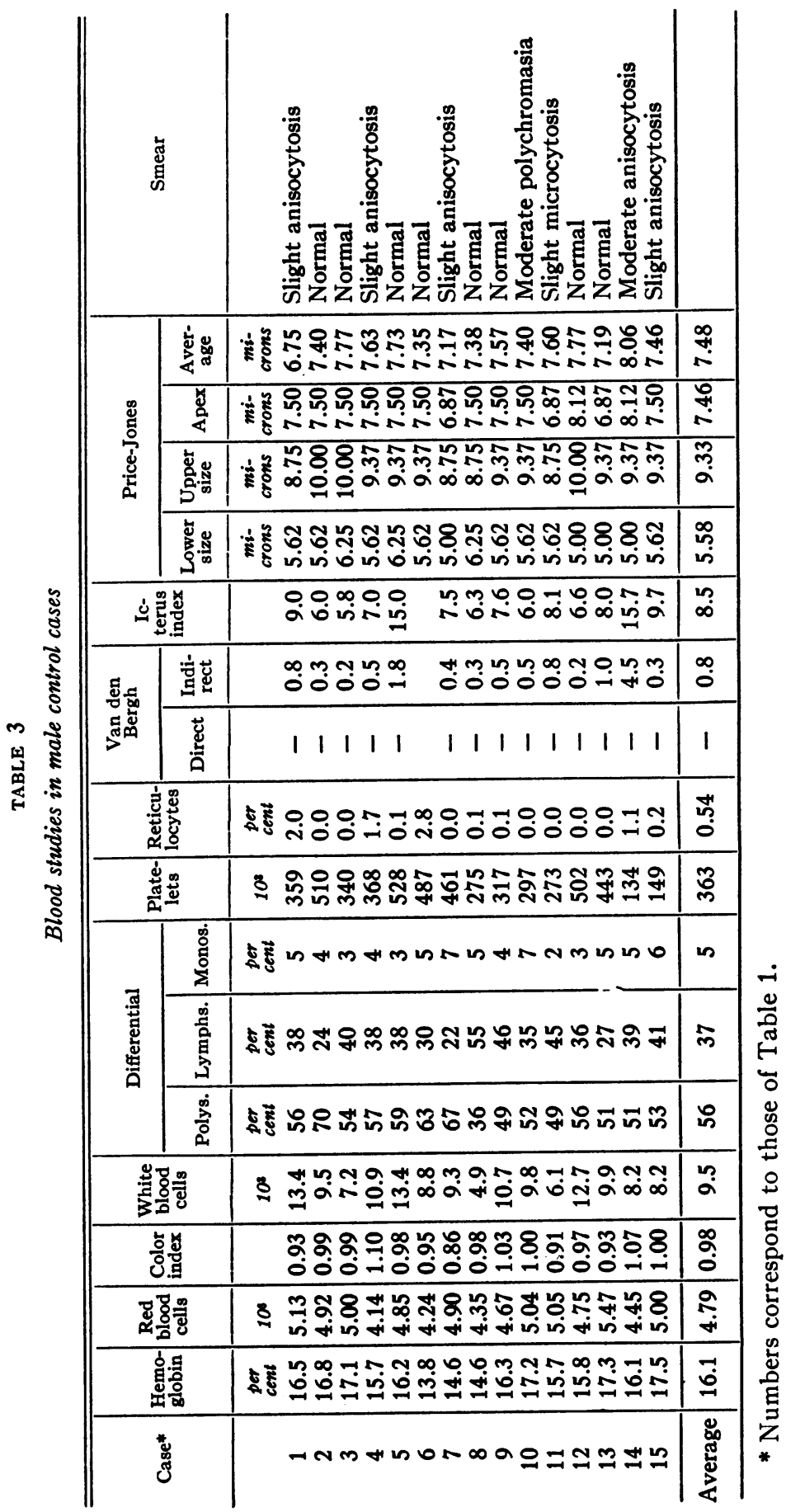




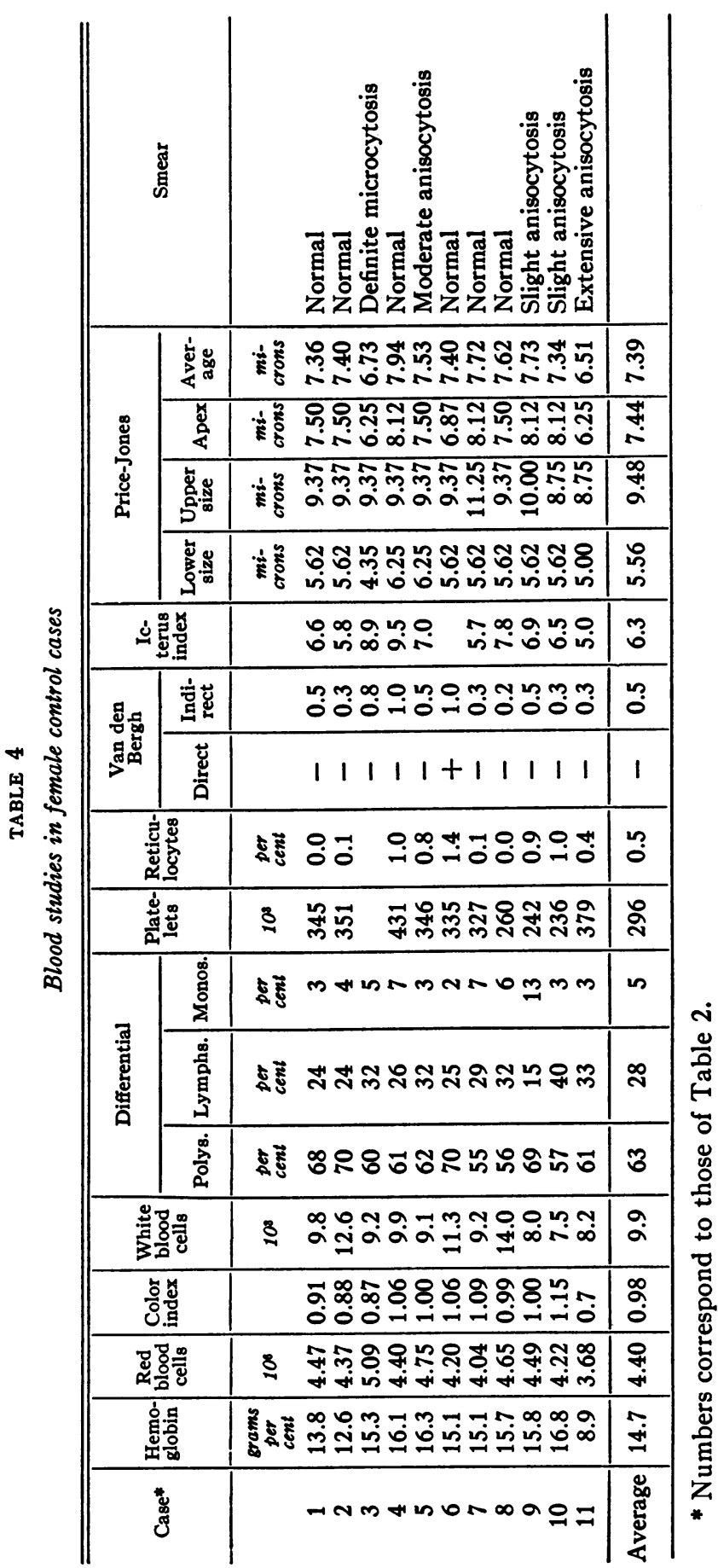




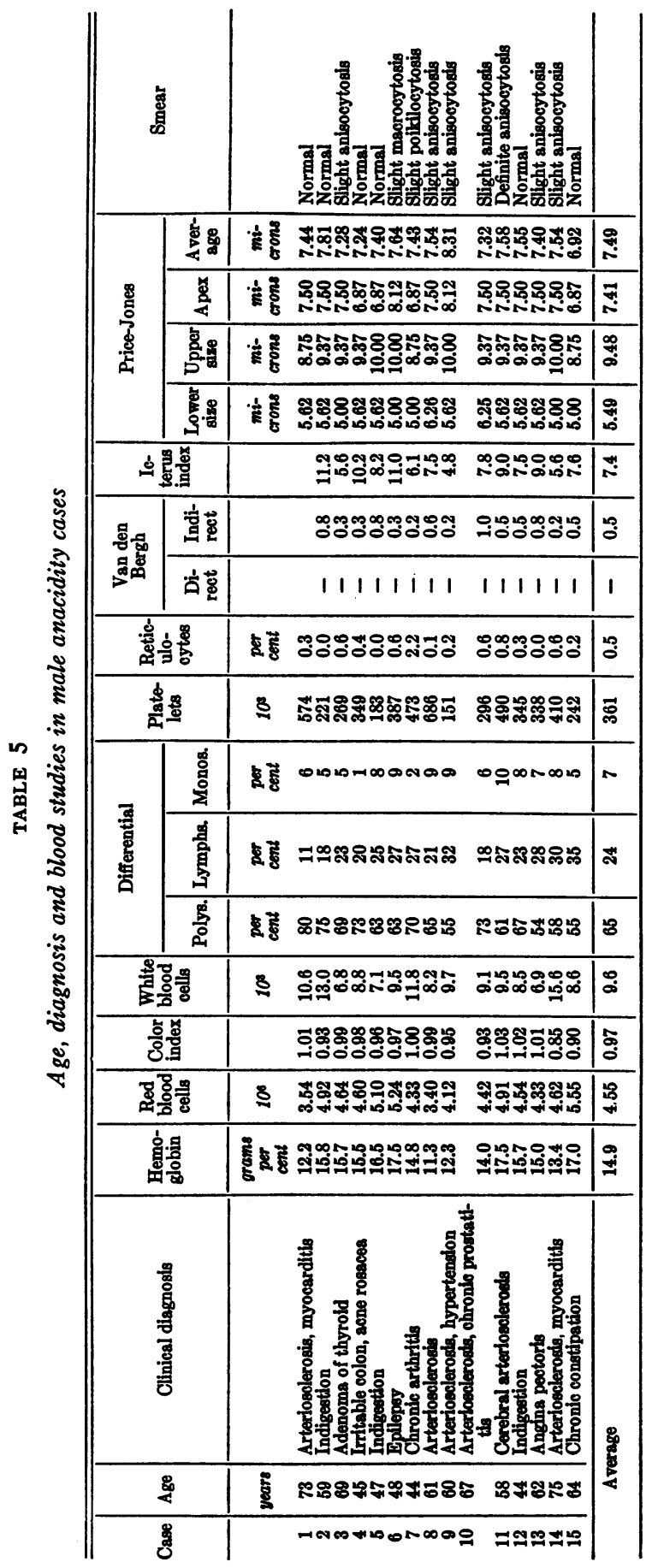


W. SCOTT POLLAND

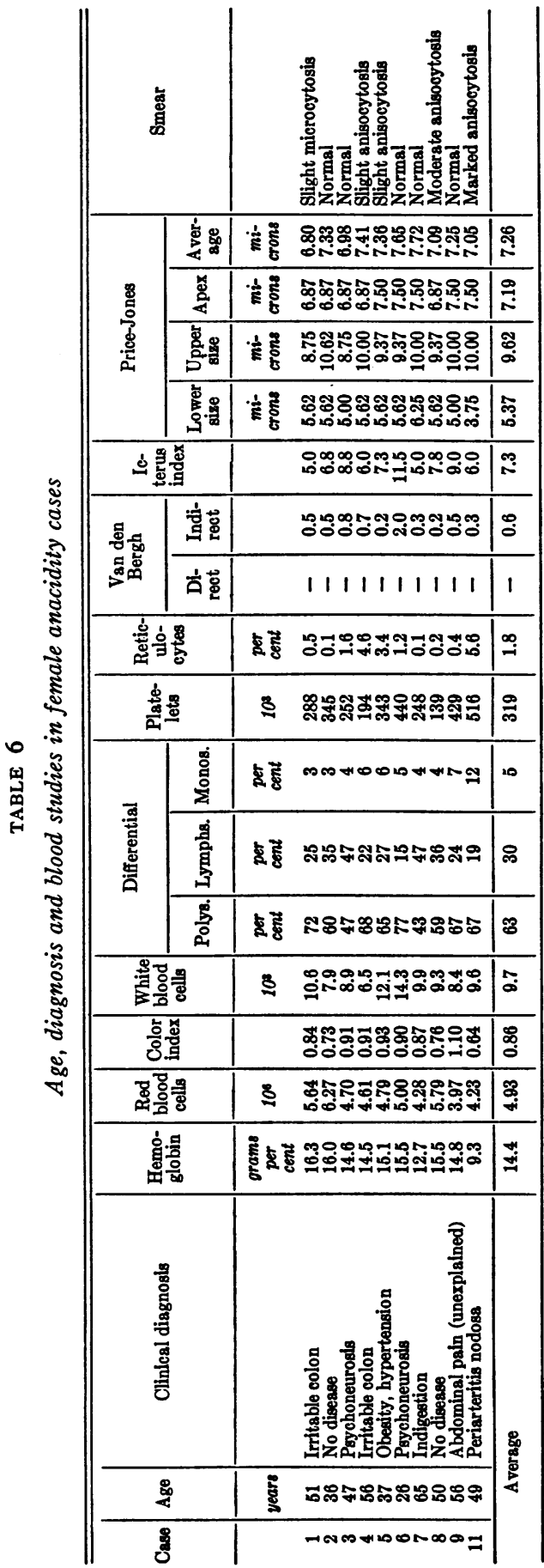




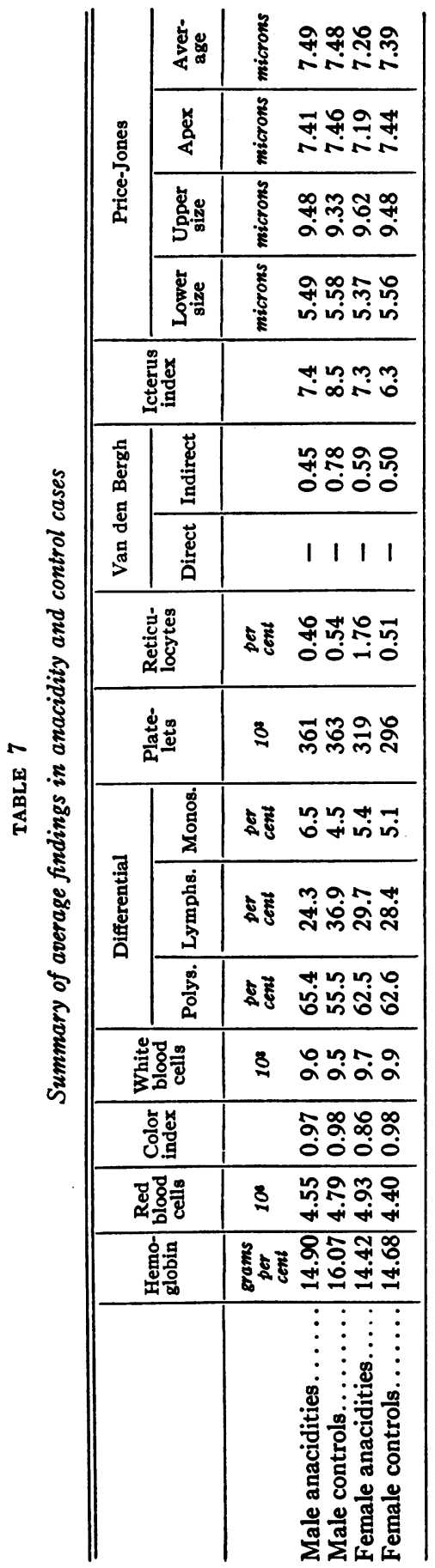




\section{DISCUSSION}

A study of the tables shows that many people with anacidity have subnormal blood counts when comparison is made with standard "normal" or "ideal" values. The point at issue, however, is not this indisputable fact but whether the anacidity bears a causal relationship to the hematological deviations. To settle this point controls are clearly necessary and when a group of people of similar age, sex and condition, but with normal gastric secretion is studied by the same methods no significant difference appears. This matter of controls has not, we believe, been properly emphasized in previous work; hence the rather generally accepted idea that anacidity per se leads to deficiency of the blood. If, for example, Case 11 of the female control series had had an anacidity she would doubtless have been considered a typical case of "achlorhydric hypochromic anemia" by most writers. A further complication comes from the fact that many of the achlorhydric women with hypochromic anemia reported in the literature had lost blood over long periods of time from uterine hemorrhage; in the present study all patients thought to have abnormal bleeding were eliminated.

Whether or not people with anacidity as a class are specially liable to develop pernicious anemia is a debatable question. Certainly there are a few isolated instances on record in which the anacidity has preceded the anemia by many years. However, some of the individuals in this series have had an anacidity to histamine for over four years and others are known to have had an anacidity to other test meals for a longer period of time without any impairment of health. In the male anacidity series, Case 1 was told that he had no acid in his stomach in 1926, Case 8 was told the same thing in 1908, and Case 9 had an anacidity to the fractional gruel meal in 1925.

Although anacidity is practically always part of the disease picture of Addisonian anemia, yet there are many gaps in our knowledge of the role of this defect in the production of the disease. Even though the two are intimately related, it is difficult to explain why the absence of free hydrochloric acid is so common in apparently healthy people.

\section{CONCLUSIONS}

The blood picture in twenty-five cases of unexplained gastric anacidity was compared with that of an otherwise similar group of people except that they had an apparently normal gastric secretion. No significant difference was noted between the two groups. No evidence is therefore forthcoming that anacidity in itself leads to anemia. 


\section{BIBLIOGRAPHY}

1. Einhorn, 1892, quoted from Faber, K., Ann. Clin. Med., 1926, iv, 788. The Intestinal Origin of Pernicious Anemia.

2. Einhorn, M., Med. R., 1903, lxiii, 321. Remarks on Achylia Gastrica and Pernicious Anemia.

3. Faber, K., Berl. klin. Wchnschr., 1913, 1, 958. Anämische Zustände bei der chronischen Achylia gastriça.

4. Weinberg, F., Ztschr. f. angew. Anat. u. Konstit., 1920, vi, 289. Der Blutbefund bei der konstitutionellen Achylia gastrica.

5. Alsberg, J., Arch. f. Verdauungskr., 1921, xxix, 328. Ein Beitrag zur Ätiologie der Achlorhydrie und Anacidität.

6. Hurst, A. F., Essays and Addresses on Digestive and Nervous Diseases and on Addison's Anemia and Asthma. Wm. Heinemann, London, 1924.

7. Hunter, C., Canad. M. A. J., 1923, xiii, 38. Analysis of Sixty Cases of Gastric Anacidity Associated Mainly with Chronic Diarrhoea and Pernicious Anemia.

8. Faber, K., and Gram, H. C., Arch. Int. Med., 1924, xxxiv, 658. Relations Between Gastric Achylia and Simple and Pernicious Anemia.

9. Schneider, J. P., and Carey, J. B., J. A. M. A., 1928, xci, 1763 . Tre Clinical Significance of Primary Achlorhydria.

10. Borgbjaerg, A., and Lottrup, M. C., Acta. med. Scandinav., 1929, lxxii, 539. Blutuntersuchungen bei der Achylie, speziell mit Rückblick auf die perniziöse Anämie.

11. Lerman, J., Pierce, F. D., and Brogan, A. J., J. Clin. Invest., 1932, xi, 155. Gastric Acidity in Normal Individuals.

12. Witts, L. J., Guy's Hosp. Rep., 1930, x, 253. Simple Achlorhydric Anemia.

13. Waugh, T. R., Arch. Int. Med., 1931, xlvii, 71. Hypochromic Anemia with Achlorhydria.

14. McCann, W. S., and Dye, J., Ann. Int. Med., 1931, iv, 918. Chlorotic Anemia with Achlorhydria, Splenomegaly and Small Corpuscular Diameters.

15. Dameshek, W., Am. J. M. Sc., 1931, clxxxii, 520. Primary Hypochromic Anemia (Erythro-normoblastic Anemia).

16. Mills, E. S., Am. J. M. Sc., 1931, clxxxii, 554. Idiopathic Hypochromemia.

17. Davies, D. T., Quart. J. Med., 1931, xxiv, 447. Studies on Achlorhydria and Anemia.

18. VanderHoof, D., and Davis, D., Am. J. M. Sc., 1932, clxxxiv, 29. Anemia of the Microcytic Type in Middle-Aged Women.

19. Bloomfield, A. L., Arch. Int. Med., 1932, 1, 328. Relations Between Primary Hypochromic Anemia and Chlorosis.

20. Ivy, A. C., Morgan, J. E., and Farrell, J. I., Surg., Gynec. and Obst., 1931, liii, 611. The Effects of Total Gastrectomy; Experimental Achylia Gastrica in Dogs with the Occurrence of a Spontaneous Anemia and Anemia of Pregnancy.

21. Conner, H. M., J. A. M. A., 1930, xciv, 606. Hereditary Aspect of Achlorhydria in Pernicious Anemia.

22. Castle, W. B., Am. J. M. Sc., 1929, clxxviii, 748. Observations on the Etiologic Relationship of Achylia Gastrica to Pernicious Anemia. I. The Effect of the Administration to Patients with Pernicious Anemia of the Contents of the Normal Human Stomach Recovered after the Ingestion of Beef Muscle. 
23. Castle, W. B., and Townsend, W. C., Am. J. M. Sc., 1929, clxxviii, 764. Ibid. II. The Effect of the Administration to Patients with Pernicious Anemia of Beef Muscle after Incubation with Normal Human Gastric Juice.

24. Castle, W. B., Townsend, W. C., and Heath, C. W., Am. J. M. Sc., 1930, clxxx, 305. Ibid. III. The Nature of the Reaction Between Normal Human Gastric Juice and Beef Muscle Leading to Clinical Improvement and Increased Blood Formation Similar to the Effect of Liver Feeding.

25. Castle, W. B., Heath, C. W., and Strauss, M. B., Am. J. M. Sc., 1931, clxxxii, 741. Ibid. IV. A Biologic Assay of the Gastric Secretion of Patients with Pernicious Anemia Having Free Hydrochloric Acid and That of Patients without Anemia or with Hypochromic Anemia Having No Free Hydrochloric Acid, and of the Role of Intestinal Impermeability to Hematopoietic Substances in Pernicious Anemia.

26. Barnett, C. W., Am. J. M. Sc., 1932, clxxxiv, 24. The Significance of the Gastric Secretions in Pernicious Anemia.

27. Bloomfield, A. L., and Polland, W. S., J. A. M. A., 1929, xcii, 1508. The Diagnostic Value of Studies of Gastric Secretion.

28. Van Slyke, D. D., and Neill, J. M., J. Biol. Chem., 1924, lxi, 523. The Determination of Gases in Blood and Other Solutions by Vacuum Extraction and Manometric Measurement. I.

29. Price-Jones, C., J. Path. and Bact., 1920, xxiii, 371. The Diurnal Variation in the Sizes of Red Blood Cells. 